\title{
Influence of Temperature and Humidity on Survival of Penicillium digitatum and Geotrichum citri-aurantii
}

\author{
J. L. Smilanick and M. F. Mansour, USDA ARS, San Joaquin Agricultural Sciences Center, 9611 South Riverbend \\ Avenue, Parlier, CA 93648
}

\begin{abstract}
Smilanick, J. L., and Mansour, M. F. 2007. Influence of temperature and humidity on survival of Penicillium digitatum and Geotrichum citri-aurantii. Plant Dis. 91:990-996.

Longevity of conidia of Penicillium digitatum (cause of citrus green mold) and arthroconidia of Geotrichum citri-aurantii (cause of sour rot of citrus) was determined under controlled temperature and relative humidity $(\mathrm{RH})$ or ambient summer conditions in central California. Longevity at low RH was longer than at high RH. Hours to kill $99 \%$ of the conidia $\left(\mathrm{LT}_{99}\right)$ of nine P. digitatum isolates were determined at $50^{\circ} \mathrm{C}$ and 75 or $95 \% \mathrm{RH}$. At 75 and $95 \% \mathrm{RH}$, the $\mathrm{LT}_{99}$ was 24.9 and $4.9 \mathrm{~h}$, respectively. The $\mathrm{LT}_{99}$ was 30 and 42 days, respectively, for conidia of $P$. digitatum under ambient conditions at two outdoor locations. The $\mathrm{LT}_{99}$ of arthroconidia of G. citriaurantii from colonies cultured on potato dextrose agar was briefer than that of conidia of $P$. digitatum. At $45^{\circ} \mathrm{C}$ and 75 or $95 \% \mathrm{RH}$, the $\mathrm{LT}_{99}$ was about 4 and $2 \mathrm{~h}$, respectively, whereas at $50^{\circ} \mathrm{C}$, none was viable after $1 \mathrm{~h}$ at either humidity. Sanitation is an important practice for managing these diseases. Since there was little or no survival of either fungus after 1 day at $50^{\circ} \mathrm{C}$ and $75 \%$ RH or higher, we conclude that commercial sanitation could employ a similar regime.
\end{abstract}

Additional keywords: Geotrichum candidum, heat treatment, postharvest

Sanitation is an important component in citrus packinghouse management, because various airborne pathogens usually bridge their survival between seasons by means of resting structures that contaminate these buildings. Sanitation aims to reduce or eliminate the fungal population from all sources, thus breaking the continuity of pathogen survival in time and space between seasons. It is particularly important in the management of fungicide-resistant isolates of Penicillium digitatum (Pers.:Fr.) Sacc. (cause of citrus green mold), since fungicide-resistant isolates of this pathogen occur primarily within packinghouses in California, where fungicides are used, and not in groves, where fungicides are not used (11). Therefore, effective sanitation within packinghouses can substantially reduce fungicide resistance problems. Sanitation is also an important method to control Geotrichum citri-aurantii (Ferraris) Butler, cause of citrus sour rot, because postharvest fungicides to effectively control this disease are not registered in the United States. Both of these diseases can occur during ethylene degreening, long-

Corresponding author: J. L. Smilanick

E-mail: Jsmilanick@fresno.ars.usda.gov

Accepted for publication 19 March 2007.

doi:10.1094/PDIS-91-8-0990

This article is in the public domain and not copyrightable. It may be freely reprinted with customary crediting of the source. The American Phytopathological Society, 2007. term storage of the fruit, or delayed sales of fruit in cartons, all of which can result in severe contamination of storage rooms and boxes with conidia or arthroconidia. Currently, formaldehyde fumigation or spray applications of alcohol or quaternary ammonium compounds are used for sanitation in citrus packing and storage facilities.

Hong et al. (9) summarized information on the longevity of fungal spores, and noted that what is known about spore longevity is limited and somewhat ambiguous. In general, temperature, conidial moisture content, and the humidity of the storage atmosphere are the major factors that influence spore longevity (9). For most fungi, the length of life of spores, as measured by their ability to germinate after various periods, decreases as temperature, conidial moisture content, or equilibrium relative humidity $(\mathrm{RH})$ increase. At a fixed $\mathrm{RH}$, increasing temperature (but below that which kills spores) generally decreases the longevity of fungal spores, whereas lower temperatures (above freezing) increase longevity. The relationship between RH and viability of fungal spores does not appear to be as simple; most persist longer at lower humidity, conversely, some species die more rapidly at lower humidity; and an isolate of Aspergillus flavus was reported to lose viability rapidly at $75 \%$ $\mathrm{RH}$ while persisting much longer at lower or higher RH (27). The survival of postharvest pathogenic fungi of fresh pome fruit has been characterized (26), but little has been published about those of citrus fruit.
The objectives of this study were to determine the optimum combinations of temperature and $\mathrm{RH}$ that can kill conidia of $P$. digitatum and arthroconidia of $G$. citri-aurantii within a reasonable period of time, which could be applied in packinghouses and storage rooms for sanitation purposes in place of chemical sanitizers. We also determined the survival of conidia of $P$. digitatum at two outdoor locations under ambient conditions.

\section{MATERIALS AND METHODS}

Fungi. $P$. digitatum isolates used in this study were collected from citrus groves and packinghouses in California during 2004. Many aspects of their growth, virulence, and fungicide sensitivity have been studied (11). Isolates included the fungicide-sensitive isolates PD90, PD172, PD180, and PD182, imazalil-resistant isolates PD136 and PD149, imazalil- and thiabendazole-resistant isolates PD120 and PD130, and imazalil-, thiabendazole-, and sodium ortho-phenyl phenol-resistant isolates PD145 and PD155. The conidia employed in all experiments were collected from sporulating lesions on orange fruit. Oranges were inoculated by injection of $0.2 \mathrm{ml}$ of a suspension that contained about $1 \times 10^{6}$ spores. $\mathrm{ml}^{-1}$ about $1 \mathrm{~cm}$ beneath the rind surface (2) followed by incubation of the fruit for 7 days at $20^{\circ} \mathrm{C}$ before use. Conidia of $P$. digitatum were collected from decay lesions on oranges by brushing the surface of the lesions with a camel hair brush, and collecting conidia in a glass vial. The conidia were used immediately. The isolate of $G$. citri-aurantii used was from an infected lemon from a packinghouse in Ventura County, CA. It was grown on potato dextrose agar (PDA; Difco Laboratories, Detroit MI) plates for 2 weeks at $24^{\circ} \mathrm{C}$ before use.

In some experiments, about $2 \mathrm{~g}$ of conidia of $P$. digitatum were placed in glass vials with porous fiber cloth cover (Miracloth, Calbiochem, La Jolla, CA). The cylindrical vials were $5.5 \mathrm{~cm}$ in length, 2.5 $\mathrm{cm}$ in diameter, and had an opening $2 \mathrm{~cm}$ in diameter. The vials were placed inside rooms of known and stable temperature and $\mathrm{RH}$, or they were placed in outdoor locations where temperature and $\mathrm{RH}$ were recorded hourly. In subsequent experiments, about $1 \mathrm{~g}$ of conidia was dispersed in a 2 by $3 \mathrm{~cm}$ plastic weigh boat, and then placed inside humidity controlled containers at various temperatures. In both cases, 
small samples of conidia were withdrawn at intervals to determine their germinability.

Arthroconidia of G. citri-aurantii were collected from PDA cultures by flooding the colonies with sterile water containing $0.01 \% \quad(\mathrm{wt} / \mathrm{vol})$ Triton X-100 (Sigma Chemical Co., St Louis, MO). A dense suspension was prepared that contained about $2 \times 10^{6}$ arthroconidia.ml ${ }^{-1}$, as determined with a spectrophotometer (2). Sterile wood craft sticks, $11.3 \mathrm{~cm}$ in length, 1 $\mathrm{cm}$ wide, and $2 \mathrm{~mm}$ thick, were placed in the suspension for $2 \mathrm{~min}$, dried in air under a sterile laminar-air flow hood for several minutes, then placed inside humidity controlled containers at various temperatures. A single stick sample containing the arthroconidia was withdrawn at intervals to determine their germinability. To resuspend the arthroconidia, the sticks were suspended in sterile water and vortexed at high speed for $1 \mathrm{~min}$.

The germinability of conidia of $P$. digitatum was determined by the preparation of dense initial suspensions that contained about $1 \times 10^{6}$ conidia, as determined with a spectrophotometer (2). Then a series of dilutions was prepared, $10 \mu \mathrm{l}$ of each dilution was plated on PDA, and each was incubated at $25^{\circ} \mathrm{C}$. Arthroconidial suspensions were diluted but not adjusted before dilution, because the density of suspensions recovered from the sticks was not high. After incubation for $18 \mathrm{~h}$, the conidia or arthroconidia were stained with acidfuchsin and examined by light microscopy $(\times 100)$. The acid-fuchsin $(0.1 \mathrm{~g}$ acid fuchsin, $100 \mathrm{ml}$ lactic acid, and $100 \mathrm{ml}$ deionized water) stopped germination and improved contrast of the conidia or arthroconidia (25). They were considered to have germinated when the length of the germ tube was equal to one-half of their diameter (19). In some experiments, unstained conidia or arthroconidia were incubated on PDA for periods as long as 3 to 5 days, to determine if germination had been delayed rather than stopped by thermal treatments.

Thermal and humidity treatments. $\mathrm{RH}$ and temperature were measured hourly during experiments with a temperature- $\mathrm{RH}$ logger (HOBO Model U12, Onset Computer Corp., Bourne, MA). The accuracy of these loggers was compared to measurements of temperature by a precision mercury thermometer (Miller and Weber, Inc., New York) and to measurements of RH by a chilled-mirror psychrometer (Model M2-Plus, General Eastern Instruments, Woburn, MA). As indicated by the manufacturer of the temperature- $\mathrm{RH} \log$ gers, the temperature accuracy was high throughout the ranges used in our studies, while RH measurement accuracy was excellent at intermediate $\mathrm{RH}$ and less so above $95 \%$.

In a preliminary study to evaluate the longevity of conidia of $P$. digitatum isolate
PD90, about $2 \mathrm{~g}$ of conidia were placed inside glass vials with a porous fiber cloth cover at the top to allow for gas exchange. Vials were placed in incubators at $1^{\circ} \mathrm{C}$ with $99 \% \mathrm{RH}, 5^{\circ} \mathrm{C}$ with $86 \% \mathrm{RH}, 10^{\circ} \mathrm{C}$ with $85 \% \mathrm{RH}, 20^{\circ} \mathrm{C}$ with $54 \% \mathrm{RH}, 25^{\circ} \mathrm{C}$ with $37 \% \mathrm{RH}, 30^{\circ} \mathrm{C}$ with $47 \% \mathrm{RH}$, or $40^{\circ} \mathrm{C}$ with $19 \% \mathrm{RH}$. Three replicate vials of conidia were placed in each environment. A representative sample was collected weekly, and germination was assessed to determine the viability of the conidia. Samples were collected for 10 weeks. Temperature-RH loggers were placed in each. Temperature changed no more than $0.5^{\circ} \mathrm{C}$ and $\mathrm{RH}$ no more than $5 \%$ during this experiment.

In subsequent experiments, the longevity of $P$. digitatum conidia or $G$. citriaurantii arthroconidia was determined in a sealed plastic container with two asymmetrical compartments that shared a common head space (1.13-liter capacity; Rubbermaid Inc., Wooster, OH). The larger compartment was $12 \mathrm{~cm}$ long, $12 \mathrm{~cm}$ wide, and $3 \mathrm{~cm}$ deep. The smaller compartment was $12 \mathrm{~cm}$ long, $8 \mathrm{~cm}$ wide, and $3 \mathrm{~cm}$ deep. In the larger compartment, $200 \mathrm{ml}$ of saturated salt solution were present. The conidia or arthroconidia, and in some tests, a $\mathrm{RH}$ and temperature logger, resided in the smaller compartment. RH of 95,75 , and $32 \%$ were maintained within the compartments using oversaturated solutions of $\mathrm{K}_{2} \mathrm{SO}_{4}, \mathrm{NaCl}$, or $\mathrm{MgCl}_{2}$ (Sigma), respectively.

Five similar experiments that assessed survival of conidia of $P$. digitatum under conditions of controlled temperature and $\mathrm{RH}$ were conducted. Each experiment was done once. In a first experiment, three replicate vials containing conidia of $P$. digitatum isolate PD90 were kept under a constant temperature at 40 or $45^{\circ} \mathrm{C}$ at an $\mathrm{RH}$ of 95,75 , or $32 \%$. Germination of conidia was determined weekly for 3 weeks. In a second experiment, conidia of $P$. digitatum isolate D201 were incubated within three replicate vials at $35,40,45$, or $50^{\circ} \mathrm{C}$ at a $\mathrm{RH}$ of 95,75 , or $32 \%$. Germination of conidia was determined after 4,7 , and 12 days. In a third experiment, conidia of $P$. digitatum isolate PD90 were incubated within three replicate vials at 40,45 , or $50^{\circ} \mathrm{C}$ at a $\mathrm{RH}$ of 95,75 , or $32 \%$. Germination of conidia was determined after 1 , 2, 3, 7, and 15 days. In a fourth experiment, conidia of $P$. digitatum isolate PD90 were incubated within three replicate vials at 45 or $50^{\circ} \mathrm{C}$ at a $\mathrm{RH}$ of 95 or $75 \%$. Germination of conidia was determined after $1,2,24,36,48$, and $60 \mathrm{~h}$. In the fifth experiment with controlled temperature and $\mathrm{RH}$, conidia of nine isolates of $P$. digitatum (fungicide-sensitive isolates PD172, PD180, and PD182, imazalil-resistant isolates PD136 and PD149, imazalil- and thiabendazole-resistant isolates PD120 and PD130, and imazalil-, thiabendazole-, and sodium ortho-phenyl phenol-resistant isolates PD145 and PD155), each in a single vial for each combination of $\mathrm{RH}$ and temperature, were placed at $50^{\circ} \mathrm{C}$ at 75 or $95 \%$ RH. Germination of conidia was determined every $2 \mathrm{~h}$ for $24 \mathrm{~h}$. The fourth and fifth experiments were conducted specifically to determine the $\mathrm{LT}_{99}$ values (the duration in days or hours required to inhibit germination of $99 \%$ of spores) for the combinations of $\mathrm{RH}$ and temperature tested.

An experiment to assess survival of arthroconidia of G. citri-aurantii under conditions of controlled temperature and $\mathrm{RH}$ was conducted. Arthroconidia on craft wood sticks were placed at 40,45 , or $50^{\circ} \mathrm{C}$ at 75 or $95 \%$ RH. Germination of arthroconidia was determined from two replicate craft wood sticks collected hourly for a period of $12 \mathrm{~h}$. The experiment was repeated.

Two experiments were conducted to determine the longevity of conidia of $P$. digitatum isolate PD90 under natural ambient summer conditions in the San Joaquin Valley of California. Two locations were selected, and the conidia were placed to avoid direct sunlight. The first location (Parlier) was within a tree at a height of $1.5 \mathrm{~m}$ in Fresno County (longitude $\mathrm{N}$ $36^{\circ} 35.789^{\prime}$, latitude $\mathrm{W} 119^{\circ} 30.803^{\prime}$ ), and the second location (Lindcove) was within a citrus grove in Tulare County (longitude $\mathrm{N} 36^{\circ} 21.607^{\prime}$, latitude $\mathrm{W} 119^{\circ} 03.595^{\prime}$ ) at a height of $1 \mathrm{~m}$. About $2 \mathrm{~g}$ of conidia were placed inside glass vials as previously described with a porous fiber cloth cover at the top to allow for gas exchange. At each location, temperature and $\mathrm{RH}$ were recorded hourly (HOBO Model U12). Germination of conidia was determined weekly for a period of 16 weeks.

Statistical analyses. The percentage of germination was calculated, and mean values and their standard deviations are reported. Probit analysis (SPSS 14.5, Chicago, IL) was applied to estimate the time in hours or days, with $95 \%$ confidence intervals, when germination decreased by $99 \%\left(\mathrm{LT}_{99}\right)$ compared to that of the initial germinability of the conidia or arthroconidia (5). Before the $\mathrm{LT}_{99}$ was calculated from germination counts, tests for normality and homogeneity of variance were applied.

\section{RESULTS}

In a preliminary test that assessed germination after storage in wide range of static conditions, temperatures of 1,5 , or $10^{\circ} \mathrm{C}$ (with $\mathrm{RH} 99,86$, or $85 \%$, respectively) had little or no effect on germination of $P$. digitatum conidia during the 10week period of the experiment (Fig. 1). At 20 or $25^{\circ} \mathrm{C}$ (with RH 54 and $37 \%$, respectively), the decline in germination percentage was moderate at the end of this period. At $30^{\circ} \mathrm{C}$ with $\mathrm{RH} 47 \%$, there was a sharp decline in germinability of conidia after 8 weeks of exposure, although at the end of 
the 10-week storage period, $8 \%$ germinated. However, at $40^{\circ} \mathrm{C}$ with $19 \% \mathrm{RH}$, germination declined relatively rapidly, and none was observed after 9 weeks.

In the first experiment that assessed survival of conidia of $P$. digitatum at 40 or $45^{\circ} \mathrm{C}$ and $\mathrm{RH}$ of 32,75 , or $95 \%$, increasing temperature and $\mathrm{RH}$ both reduced the percentage of germinable conidia (Fig. 2). At either temperature with $95 \% \mathrm{RH}$, very few spores were viable after 1 week. The germination percentage observed was similar if the germination was counted after $18 \mathrm{~h}$

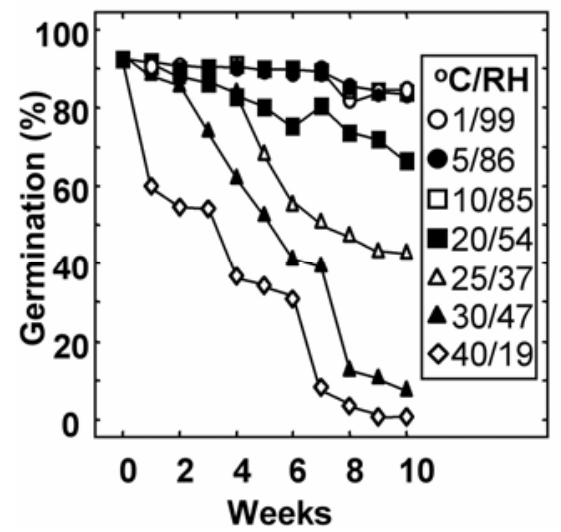

Fig. 1. Effect of different combinations of temperature and relative humidity on the longevity (as determined by $\%$ germination) of conidia of Penicillium digitatum isolate PD90. Germination was assessed from conidia removed weekly for 10 weeks.

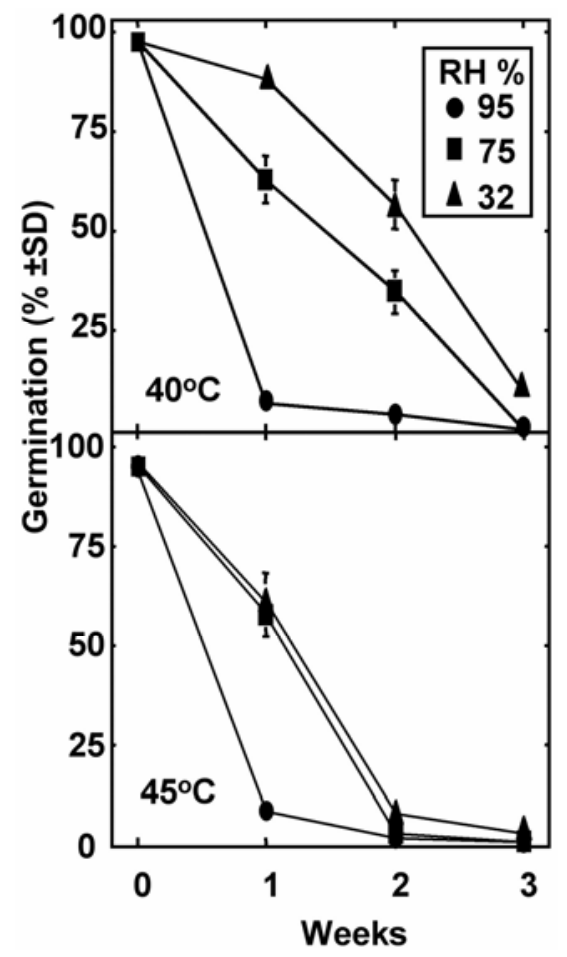

Fig. 2. Longevity of conidia of Penicillium digitatum isolate PD90 stored at a constant temperature of 40 or $45^{\circ} \mathrm{C}$ at a relative humidity of 32,75 , or $95 \%$. Germination percentage was assessed from conidia removed weekly for 3 weeks. or up to 5 days on PDA after exposure of the conidia to controlled temperature and $\mathrm{RH}$ conditions. This indicates that the ability of conidia to germinate was not delayed but stopped.

In the second experiment that assessed survival of conidia of $P$. digitatum at 35 , 40,45 , or $50^{\circ} \mathrm{C}$ and $\mathrm{RH}$ of 32,75 , or $95 \%$, increasing temperature and RH both reduced the percentage of germinable conidia (Fig. 3). At 40,45 , or $50^{\circ} \mathrm{C}$ with $95 \%$ $\mathrm{RH}$, very few spores were viable after 4 days, while at $35^{\circ} \mathrm{C}$ or lower $\mathrm{RH}$, germination was higher. At $50^{\circ} \mathrm{C}$, regardless of $\mathrm{RH}$, none of the conidia germinated after 4 days exposure, which was the briefest exposure period evaluated. As in the prior experiment, the germination percentage observed was similar if the germination was counted after $18 \mathrm{~h}$ or up to 5 days on PDA after exposure of the conidia to the controlled temperature and $\mathrm{RH}$ conditions.

In the third and fourth experiments that assessed survival of conidia of $P$. digitatum at 40,45 , or $50^{\circ} \mathrm{C}$ and $\mathrm{RH}$ of 32,75 , or $95 \%$, increasing temperature and $\mathrm{RH}$ both reduced the percentage of germinable conidia as in prior experiments (Fig. 4). Data from both tests were combined to determine $\mathrm{LT}_{99}$ values over a wide range of exposure periods. At these temperatures, mortality of conidia at $32 \% \mathrm{RH}$ occurred very slowly compared to that at higher RH. At 45 and $50^{\circ} \mathrm{C}$ with $95 \% \mathrm{RH}$, the $\mathrm{LT}_{99}$ predicted values were very brief, only 7.8 and $4.9 \mathrm{~h}$, respectively.

In the fifth experiment, testing the effect of $50^{\circ} \mathrm{C}$ at 75 or $95 \% \mathrm{RH}$ on fungicide- sensitive and -resistant isolates of $P$. digitatum, all isolates responded similarly at $95 \%$ RH with $\mathrm{LT}_{99}$ of about $5 \mathrm{~h}$ (Fig. 5). The $\mathrm{LT}_{99}$ values at $75 \% \mathrm{RH}$ indicated that there was some variation among the isolates; the $\mathrm{LT}_{99}$ of isolate PD155 was lower at $11.5 \mathrm{~h}$, and that of isolate PD120 was higher at $33.5 \mathrm{~h}$, than most of the other isolates, which had $\mathrm{LT}_{99}$ values between 20 and $30 \mathrm{~h}$.

The ability of conidia to germinate after exposure to summer conditions at both locations in the San Joaquin Valley declined by one-half approximately every 2 weeks (Fig. 6). Environmental conditions at both locations were similar, although occasionally direct sunlight was present briefly on the sample site at times at the Parlier location that slightly increased the mean temperatures and greatly increased the daily peak temperatures. This period ( 8 July to 30 August 2005) was exceptionally hot. Estimates of $\mathrm{LT}_{99}$ (95\% confidence interval) at the Lindcove and Parlier locations were $30.2(27.2,34.3)$ and $41.6(34.2$, 55.1) days, respectively.

The ability of arthroconidia of G. citriaurantii to germinate declined more rapidly than that of conidia of $P$. digitatum (Fig. 7). However, unlike $P$. digitatum, after exposure of the arthroconidia to the controlled temperature and $\mathrm{RH}$ conditions, the percentage of germination observed increased when germination counts made after $18 \mathrm{~h}$ were compared to those made after 5 days incubation on PDA. This indicates the ability of some arthroconidia to germinate was delayed by the environ-

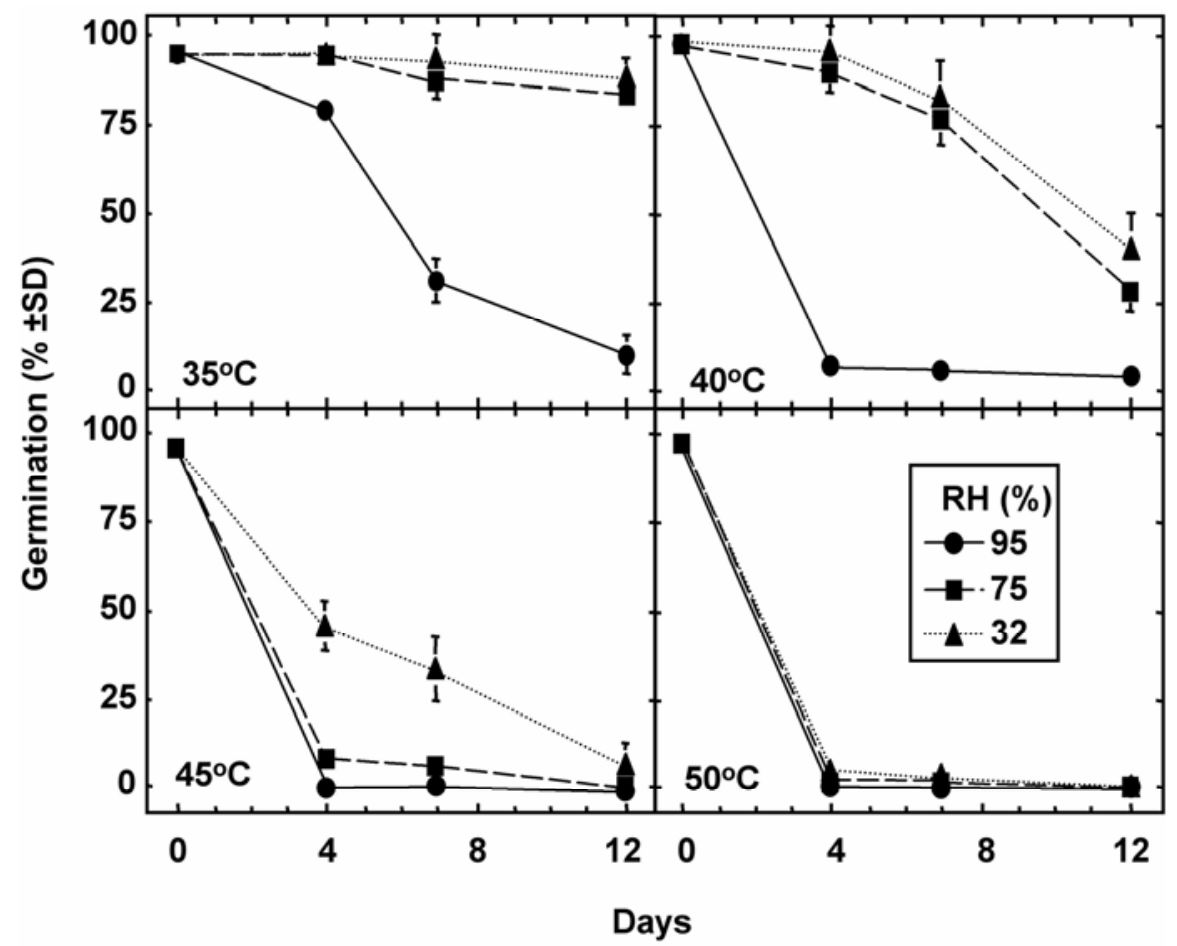

Fig. 3. Longevity of conidia of Penicillium digitatum isolate D201 stored at a constant temperature of $35,40,45$, or $50^{\circ} \mathrm{C}$ at a relative humidity of 32,75 , or $95 \%$. Germination was assessed from conidia removed after 4,7 , and 12 days of storage. 
mental treatments before the ability to germinate was stopped. At $50^{\circ} \mathrm{C}$ with both 75 and $95 \% \mathrm{RH}$, germination of all arthroconidia was inhibited completely after $2 \mathrm{~h}$ of exposure. At $45^{\circ} \mathrm{C}$ with $95 \% \mathrm{RH}$, germination of all arthroconidia was inhibited completely after $3 \mathrm{~h}$ of exposure.

\section{DISCUSSION}

Survival of conidia of other postharvest pathogens is similar in many respects to that of $P$. digitatum. Spotts (26) characterized the longevity of several fungi that cause postharvest decay of pome fruit. $\mathrm{He}$ reported that conidia of $P$. expansum, the cause of postharvest blue mold of pome fruit, and Botrytis cinerea, the cause of postharvest gray mold, persisted about 40 days and more than 63 days, respectively, on the surface of pear fruit in orchards. Under controlled conditions, increasing $\mathrm{RH}$ and temperature decreased their persistence. Moyano and Melgarejo (17) reported significant differences in survival of conidia of $B$. cinerea associated with temperature, $\mathrm{RH}$, and their interaction. High temperatures caused a decrease in survival of conidia; at $40^{\circ} \mathrm{C}$, conidia survived for only 7 days at $80 \% \mathrm{RH}$, whereas at $22^{\circ} \mathrm{C}$, they survived for 30 to 90 days depending on the RH.

Prior research on the influence of RH on the survival of conidia of other fungi can provide an interpretation of our findings with conidia of $P$. digitatum and arthroconidia of $G$. citri-aurantii. The moisture content of conidia is a function of $\mathrm{RH}$, and the moisture content of fungal conidia spans a wide range, from 8 to $88 \%$ of fresh weight, depending upon species and conditions of growth (6). Fungal conidia, and spores of bacteria and seeds, invariably exhibit an S-shaped plot of water sorption as a function of $\mathrm{RH}$. Between 0 and $10 \%$ $\mathrm{RH}$, most biological materials exhibit a sharp increase to as much as $5 \%$ water content. A more gradual increase is observed between 10 and about $80 \% \mathrm{RH}$, to a water content of about 10 to $25 \%$. This water is considered to be "bound" at charged or polar sites with varying degrees of tightness (12). Above $80 \% \mathrm{RH}$, there is a sharp increase in the water content to a value usually in excess of $35 \%$ at $100 \%$ RH. This is considered to represent "bulk" water accumulating in the regions between hydrated molecules (12). Fahey et al. (4) reported that damp conidia of Neurospora (about 65\% water content) exhibited significant metabolic activity, as evidenced by a reduction of oxidized to reduced glutathione (GSH), degradation of GSH, and changes in the pool sizes of certain amino acids, whereas dry conidia had little metabolic activity. Dry conidia had greater longevity than wet conidia. Furthermore, dry and quasi-dry conidia had substantial resistance to heating at $100^{\circ} \mathrm{C}$, whereas wet conidia had no resistance. They stated that dehydration appears to be essential to thermal resistance in conidia, probably via a direct effect upon the stability of macromolecules. Dry proteins survive heating more readily than wet proteins, and lyophilized enzymes have withstood extended heating under vacuum at temperatures in excess of $200^{\circ} \mathrm{C}$ (12). Rotem (20) found longevity of mycelium of Alternaria porri f. sp. solani at all humidities decreased with increasing temperature. The optimal relative humidities for longevity were from 7 to $38 \%$, depending upon the temperature. An increase in humidity was associated with a sharp decrease in longevity, and a decrease in RH with a slow decline. Similar effects were found in relation to the longevity of spores. Mycelium and spores died within $2 \mathrm{~h}$ at 90 and $60^{\circ} \mathrm{C}$, respectively. Although the survival rate of this fungus is much greater at low temperature, any increase of atmospheric humidity depresses it markedly. Teitell (27) found a narrow band of $\mathrm{RH}$ which had a pronounced lethal effect on conidia of several isolates of Aspergillus flavus. At $29^{\circ} \mathrm{C}$, this lethal RH was $75 \%$; conidial survival was not affected at relative humidities of $73 \%$ or lower and $77 \%$ or higher (27).

The longevity of conidia of $P$. digitatum and arthroconidia of $G$. citri-aurantii that we report, and the observation that it was inversely proportional to both temperature and $\mathrm{RH}$, is similar to reports about the longevity of many other fungi. The longevity of mycelium and spores of several fungi, including Penicillium italicum, was diminished in 1 day at $53^{\circ} \mathrm{C}$ when the $\mathrm{RH}$ was $74 \%$ or higher (20). Schein and Rotem (22) stored uredospores of the bean rust fungus, Uromyces phaseoli, under different temperatures and $\mathrm{RH}$, and reported that as the temperature and humidity of the storage atmosphere increased, the longevity of spores, as determined by their germinability, declined, and this decrease was inversely proportional to both temperature and humidity of the atmosphere. The RH during storage of the conidia of Helmin-

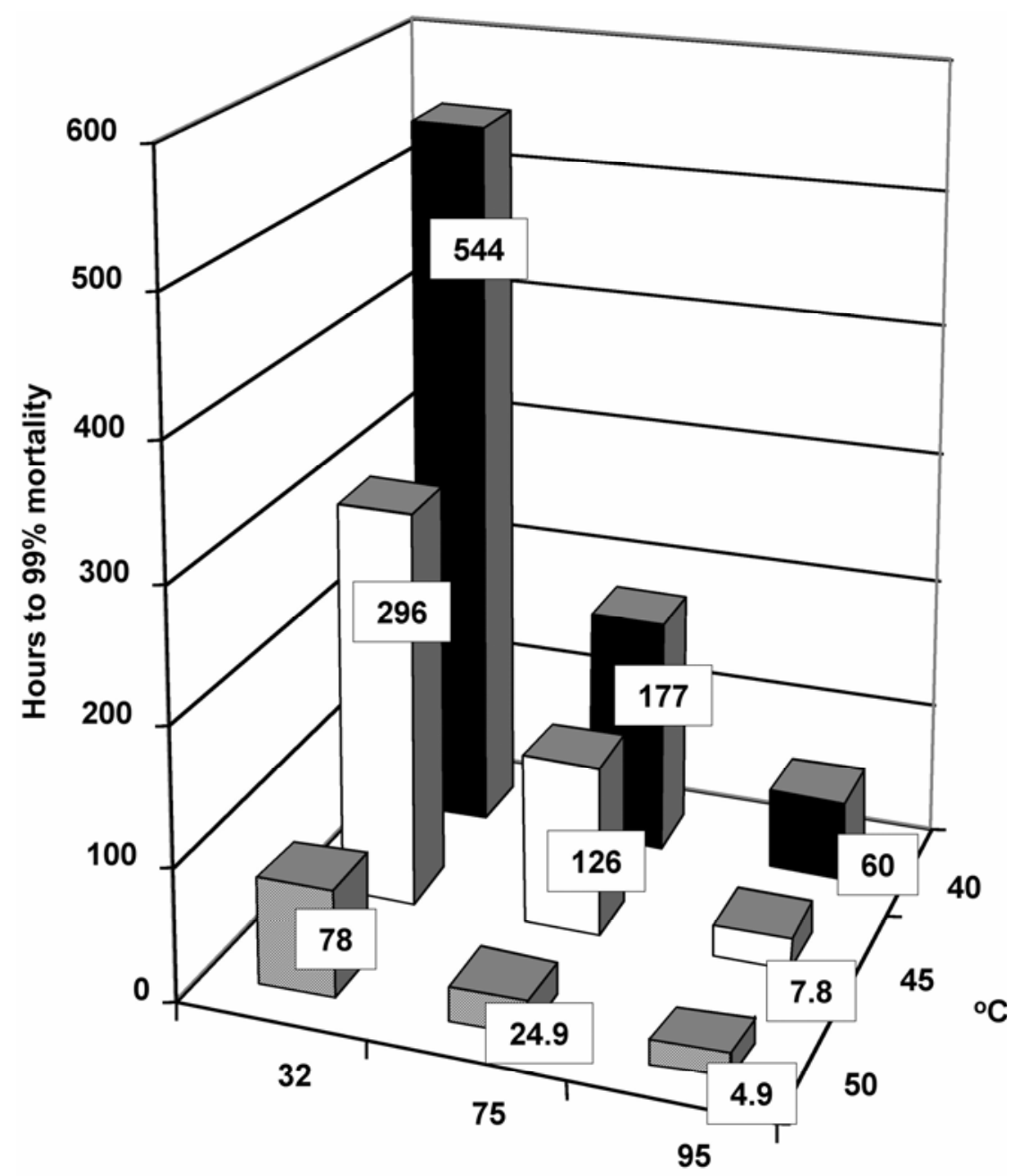

Relative humidity (\%)

Fig. 4. Longevity of conidia of Penicillium digitatum isolate PD90 stored at a constant temperature of 40,45 , or $50^{\circ} \mathrm{C}$ at a relative humidity of 95,75 , or $32 \%$. Values are the times in hours when the percentage of conidia that could germinate had declined by $99 \%\left(\mathrm{LT}_{99}\right)$, as estimated by probit analysis. Germination percentage was assessed from conidia removed hourly when mortality was rapid, at 45 or $50^{\circ} \mathrm{C}$ at 75 or $95 \% \mathrm{RH}$, or daily when mortality was slow, at $40^{\circ} \mathrm{C}$ or at $32 \% \mathrm{RH}$ at all temperatures. Data from two experiments were combined. 
thosporium oryzae was a more important factor influencing longevity than temperature alone (18). For example, at a $\mathrm{RH}$ of $20 \%$, the conidia survived for 6 months with little loss of viability even at $31^{\circ} \mathrm{C}$, whereas at a $\mathrm{RH}$ of $95 \%$, they failed to germinate after 1 month at this temperature. Viability of conidia of Metarhizium flavoviride declined relatively rapidly at high temperatures (up to $55^{\circ} \mathrm{C}$ ) when dried to a moisture content of $19 \%$, whereas the viability of those dried to 4 to $5 \%$ moisture content declined slowly (8). Hong et al. (9), Sandhu et al. (21), and Spotts (26) have characterized the longevity of many fungi, including A. porri, Beauveria bassiana, Beauveria brongniartii, Botrytis cinerea, Helminthosporium oryzae, Metarhizium anisopliae, Mucor pyriformis, Paecilomyces farinosus, Penicillium ex- pansum, Sclerotinia sclerotiorum, and Uromyces appendiculatusm, and showed declining longevity with increasing moisture content or RH and increasing temperature. Hong et al. (10) developed models driven by conidial moisture content and temperature that predicted longevity of isolates of Beauveria bassiana. They were concerned with the shelf life of this formulated entomopathogenic fungus, and increasing temperature and humidity shortened it. Not all fungi respond in this manner, however. Temperature, and not $\mathrm{RH}$, was the main climatic factor affecting longevity of urediniospores of Tranzschelia discolor (3). A model based on temperature showed that urediniospores of $T$. discolor were critically affected by temperatures in the range 25 to $30^{\circ} \mathrm{C}$; exposure to higher temperatures resulted in a

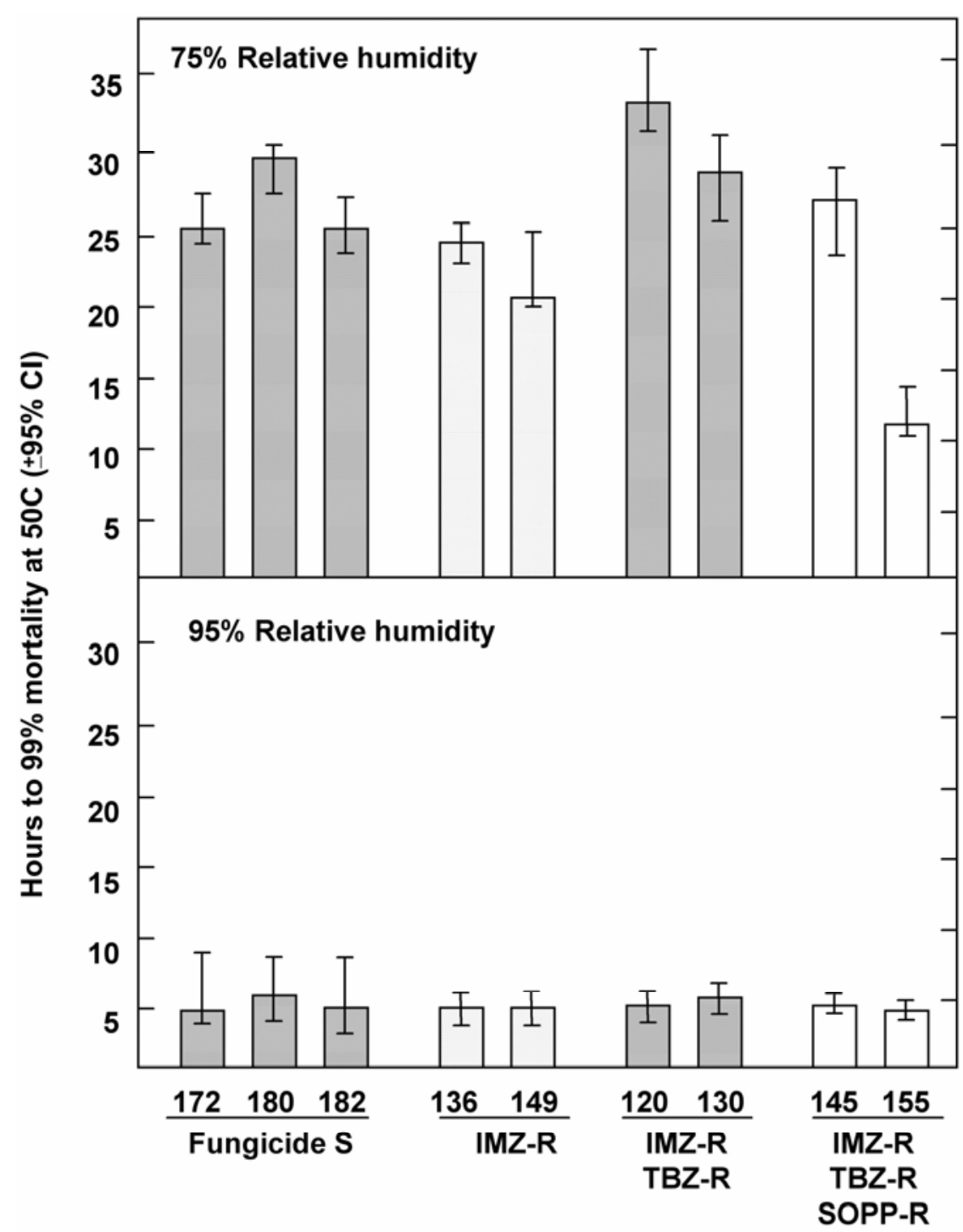

Isolate of $P$. digitatum

Fig. 5. Longevity of conidia of nine Penicillium digitatum isolates stored at a constant temperature of $50^{\circ} \mathrm{C}$ at a relative humidity of 75 or $95 \%$. Isolates were resistant (R) to the fungicides imazalil (IMZ), thiabendazole (TBZ), and sodium ortho-phenylphenate (SOPP) or sensitive (S) to all of them. Values are the times in hours when the percentage of conidia that could germinate had declined by $99 \%$ $\left(\mathrm{LT}_{99}\right)$, as estimated by probit analysis. Germination percentage was assessed from conidia removed hourly. 34-fold faster rate of decline. Temperatures above the optimum for growth generally represent a stress for fungi that reduces the longevity of their spores. For example, optimal growth of Aspergillus carbonarius occurs from 25 to $35^{\circ} \mathrm{C}$ (1); however, Leong et al. (13) reported that $37^{\circ} \mathrm{C}$ severely retarded growth and $42^{\circ} \mathrm{C}$ killed the conidia. Heat stress at $37^{\circ} \mathrm{C}$ contributed to the relatively rapid death of $A$. carbonarius spores (14). In our work and that of most others, constant and controlled conditions of temperature and humidity were applied; however, it is conceivable that prior activation of conidia or arthroconidia could influence their subsequent longevity. Lingappa and Sussman (15) reported that heat resistance declined after activation of ascospores of Neurospora tetrasperma. Activation, which consisted of 5-min incubation at $27^{\circ} \mathrm{C}$, rendered spores susceptible to substantial mortality after a 5-min "heat flash" of $65^{\circ} \mathrm{C}$. When the heat flash was applied 25 min after activation, none of the ascospores survived, whereas more than half of unactivated ascospores survived exposure for $30 \mathrm{~min}$ to $65^{\circ} \mathrm{C}$. Dry heat was less effective than wet heat in activating ascospores.

The longevity of arthroconidia of $G$. $c i$ tri-aurantii during incubation at warm temperatures was less than that of conidia of $P$. digitatum. For example, at $50^{\circ} \mathrm{C}$ with $95 \% \mathrm{RH}$, the $\mathrm{LT}_{99}$ of conidia of $P$. digitatum was about $5 \mathrm{~h}$, whereas no arthroconidia of $G$. citri-aurantii germinated after $2 \mathrm{~h}$ incubation under these conditions. At $45^{\circ} \mathrm{C}$ with $95 \% \mathrm{RH}$, the $\mathrm{LT}_{99}$ of conidia of $P$. digitatum was about $8 \mathrm{~h}$, whereas no arthroconidia of G. citri-aurantii germinated after $3 \mathrm{~h}$ incubation under these conditions. In prior work to determine the influence of hot water on the survival of these fungi, conidia of $P$. digitatum were also more resistant to heat than arthroconidia of $G$. citri-aurantii. To inactivate $99 \%$ of the conidia of $P$. digitatum in $15 \mathrm{~s}$, a water temperature of $63.9^{\circ} \mathrm{C}$ was needed, whereas only $58.8^{\circ} \mathrm{C}$ was needed to inactivate $99 \%$ of the arthroconidia of G. citriaurantii (25).

The temperatures that inactivate conidia of $P$. digitatum and arthroconidia of $G$. citri-aurantii are relatively low, and it is probably feasible to develop a 1- or 2-day thermal and humidity regime that would reliably disinfest packinghouses, contaminated harvest bins, or storage rooms. Unlike chemical sanitation, the use of heat and moisture avoids many issues including worker hazard, chemical storage, fumigant containment, corrosion, or residues. The approach that we propose is similar to that recently reported for solar disinfestation of greenhouses (24). Shlevin et al. (24) found dry heating to $60^{\circ} \mathrm{C}$ and higher with a consequent low relative humidity $(\mathrm{RH}=$ $15 \%)$ required an extended period for thermal inactivation of Fusarium oxysporum $\mathrm{f}$. sp. melonis and $F$. oxysporum $\mathrm{f}$. 
sp. radicis-lycopersici. They enhanced pathogen control by increasing moisture during the hot hours of the day; the $\mathrm{ED}_{50}$ value of thermal inactivation was reduced from 15 days to 1 day. Their system provided both high temperature (about $60^{\circ} \mathrm{C}$ ) and high RH (about $100 \%$ ). Grain mills are also disinfested by heat, although the objective is primarily to control insects. Regimes of approximately $50^{\circ} \mathrm{C}$ for 24 to 36 $\mathrm{h}$ killed all life stages of Tribolium castaneum, the red flour beetle (16), and this approach cost less than one-third that of chemical fumigation (7).

There are locations within citrus packinghouses where thermal disinfestation is particularly feasible. Treatments of sufficient temperature and humidity would require the acquisition of heaters and humidifiers and the energy to operate them. From our work, it is likely good disinfestation of both pathogens should result after a 1- or 2-day treatment of $50^{\circ} \mathrm{C}$ or more with a RH exceeding $75 \%$. It is likely the surfaces of flooring and walls may require some period to reach effective temperatures, and the length of this period is likely to vary among facilities. Disinfestation of spaces that do not contain packing equipment is more practical, because damage to the electronic components of sizing and grading equipment would be avoided. Within citrus packinghouses, chambers (degreening or "sweat" rooms) to apply ethylene gas treatments are common. In California, they incorporate heating, aircirculation, and humidity regulation because the treatment is typically conducted at $20^{\circ} \mathrm{C}$ with high humidity for several days before the fruit are packed (29). Often fruit will decay during degreening and these rooms can become severely contaminated with conidia of $P$. digitatum. Storage rooms, usually operated at $10^{\circ} \mathrm{C}$ or cooler, and containing fruit in cartons or storage boxes for periods up to months, can also

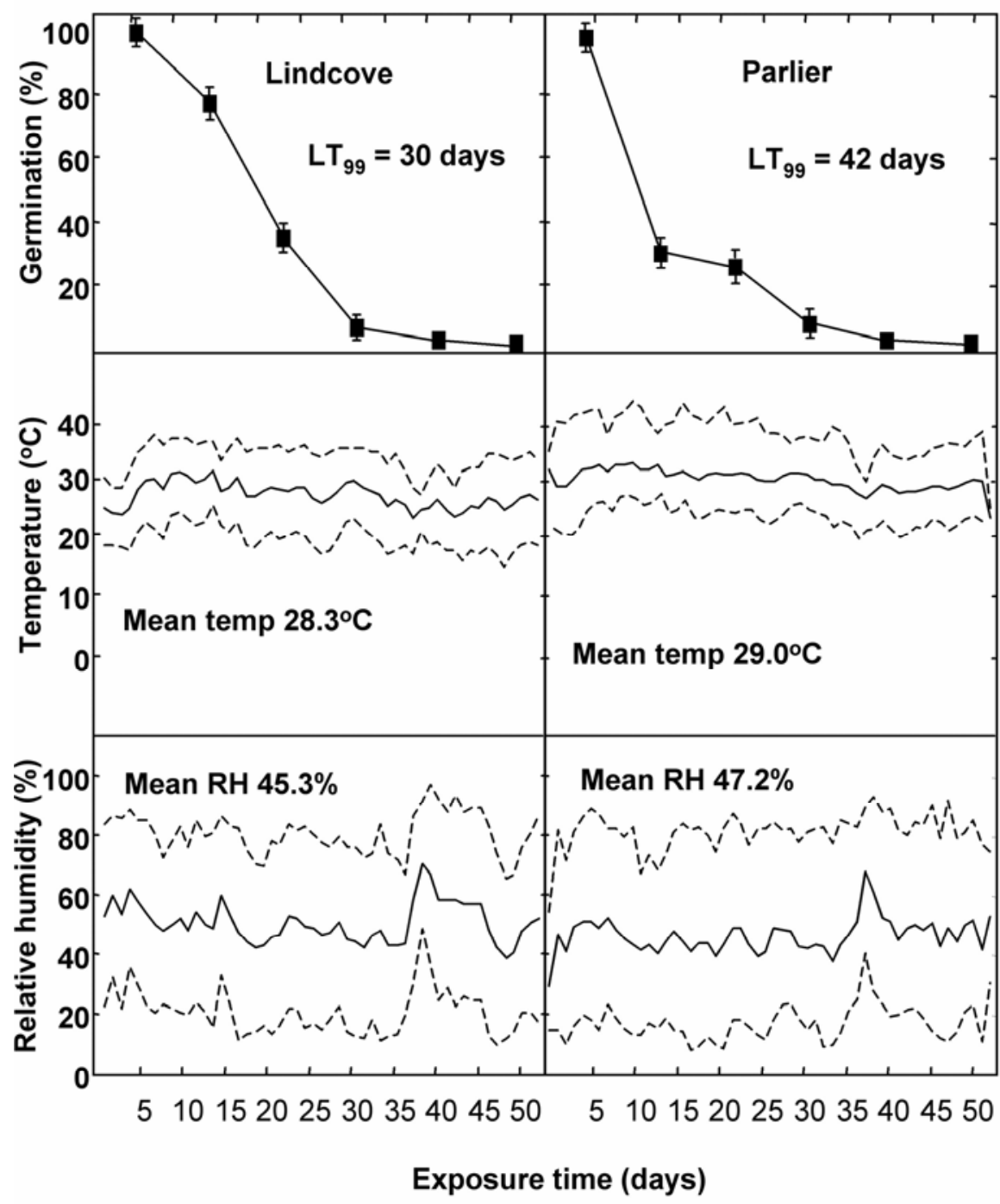

Fig. 6. Relative humidity and temperature of two outdoor locations (Lindcove and Parlier), from 8 July to 30 August 2005, where conidia of Penicillium digitatum isolate PD90 were placed. Germination (\% \pm standard deviation of four samples) was determined from conidia collected weekly. Estimates of the time in days when the percentage of conidia that could germinate had declined by $99 \%$ ( $\mathrm{LT}_{99}$ with lower and upper $95 \%$ confidence intervals) by probit analysis were $30.2(27.2,34.3)$ and 41.6 (34.2, 55.1) days, respectively, at the Lindcove and Parlier locations.

become severely contaminated with both $P$. digitatum and G. citri-aurantii. Fruit field bins and other equipment contaminated with these pathogens could also be disinfested by thermal treatment within these rooms.

The temperatures that inactivate conidia, however, are too high to be tolerated by fresh citrus fruit without risk of harm to their appearance and internal quality. Curing treatments for citrus fruit, applied to retard decay and increase chilling tolerance, are usually of 24 to $48 \mathrm{~h}$ in duration at about $35^{\circ} \mathrm{C}$; it is unlikely fruit would tolerate temperatures 10 to $15^{\circ} \mathrm{C}$ higher than this without alterations such as increases in ethanol and acetaldehyde, poor color development, decreased flavor scores, and increased weight loss $(23,28)$.

From the results presented here, it is likely conidia could survive in large numbers within California packinghouses from one harvest season to another, while those in the groves decline markedly. In our two outdoor locations, the ability of conidia to germinate was estimated to have declined by $99 \%$ by 30 or 42 days. Conversely, conidia in the protected environment of a citrus packinghouse persisted much longer. We determined the viability of conidia of $P$. digitatum weekly for 16 weeks that were

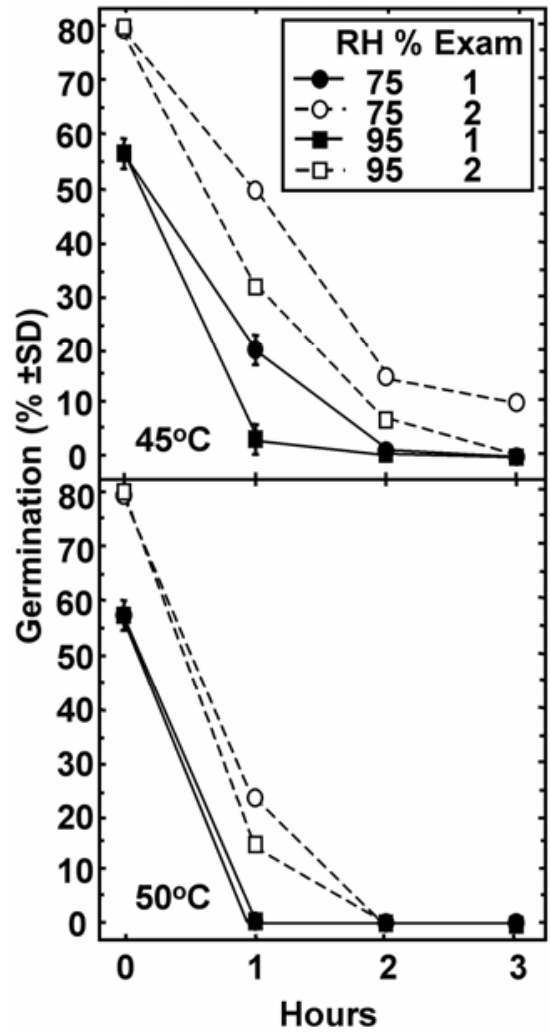

Fig. 7. Longevity of arthroconidia of Geotrichum citri-aurantii stored at a constant temperature of 45 or $50^{\circ} \mathrm{C}$ at a relative humidity of 75 or $95 \%$. Germination was assessed from arthroconidia removed hourly. Two examinations of arthroconidia germination were made, the first (exam 1) after $18 \mathrm{~h}$, and a second (exam 2) after 5 days incubation on potato dextrose agar at $24^{\circ} \mathrm{C}$. 
placed in a citrus packinghouse where daily temperatures were 20 to $30^{\circ} \mathrm{C}$ and the RH was 30 to $60 \%$ (J. L. Smilanick and M. F. Mansour, unpublished). Initially and after 16 weeks, germination was 97 and $25 \%$, respectively. Knowledgeable industry technicians stated that sanitation in Florida packinghouses is of less concern than those in California, because populations of conidia of $P$. digitatum in the humid Florida packinghouses decline rapidly, whereas those in drier California packinghouses persist for many months. Our results support their observations, and emphasize the need for packinghouse sanitation in California, particularly between harvest seasons.

\section{ACKNOWLEDGMENTS}

We thank statistician Bruce Mackey of the Biometrics Unit of USDA ARS Western Regional Research Center for advice and assistance, the California Citrus Research Board for financial assistance, Walter Stutzman of the University of California Lindcove Research and Extension Center, Exeter, CA, and David Sorenson of Fruit Growers Supply, Exeter, CA.

\section{LITERATURE CITED}

1. Belli, N., Marin, S., Sanchis, V., and Ramos, A. J. 2004. Influence of water activity and temperature on growth of isolates of Aspergillus section Nigri obtained from grapes. Int. J. Food Microbiol. 96:19-27.

2. Eckert, J. W., and Brown, G. E. 1986. Evaluation of postharvest treatments for citrus fruits. Pages 92-97 in: Methods for Evaluating Pesticides for the Control of Plant Diseases. K. D. Hickey, ed. American Phytopathological Society, St. Paul, MN.

3. Ellison, P. J., McFadyen, L. M., Cullis, B. R., and Kable, P. F. 1995. Survival of dispersed urediniospores of Tranzschelia discolor Fckl. (Tranz. Litv.) on leaves of Prunus domestica L. cv. 'd'Agen' in spring and summer in the Murrumbidgee irrigation areas. Aust. J. Agric. Res. 39:847-856.

4. Fahey, R. C., Mikolajczyk, S. T., and Brody, S. 1978. Correlation of enzymatic activity and thermal resistance with hydration state in ungerminated Neurospora conidia. J. Bacteriol. 135:868-875.

5. Finney, D. J. 1971. Probit Analysis. Cambridge University Press, New York.

6. Hawker, L. E., and Madelin, M. F. 1976. The dormant spore. Pages 1-72 in: The Fungal Spore: Form and Function. D. J. Weber and W. M. Hess, eds. John Wiley \& Sons, New York.

7. Heaps, J. W., and Black, T. 1994. Using portable rented electric heaters to generate heat and control stored product insects. Assoc. Operative Millers Bull., July 1994, pp 6408-6411.

8. Hedgecock, S. 1995. Influence of moisture content on temperature tolerance and storage of Metarhizium flavoviride conidia in an oil formulation. Biocontrol Sci. Technol. 5:371378.

9. Hong, T. D., Ellis, R. H., and Moore, D. 1997. Development of a model to predict the effect of temperature and moisture on fungal spore longevity. Ann. Bot. 79:121-128.

10. Hong, T. D., Gunn, J., Ellis, R. H., Jenkins, N. E., and Moore, D. 2001. The effect of storage environment on the longevity of conidia of Beauveria bassiana. Mycol. Res. 105:597-602.

11. Kinay, P., Mansour, M. F., Gabler, F. M., Margosan, D. A., and Smilanick, J. L. 2007. Characterization of fungicide-resistant isolates of Penicillium digitatum collected in California. Crop Prot. 26:647-656.

12. Kuntz, I. D., Jr., and Kauzmann, W. 1974. Hydration of proteins and polypeptides. Adv. Protein Chem. 28:239-345.

13. Leong, S. L., Hocking, A. D., and Pitt, J. I. 2004. Occurrence of fruit rot fungi (Aspergillus section Nigri) on some drying varieties of irrigated grapes. Aust. J. Grape Wine Res. 10:83-88.

14. Leong, S. L., Hocking, A. D., and Scott, E. S. 2006. Effects of water activity and temperature on the survival of Aspergillus carbonarius spores in vitro. Lett. Appl. Microbiol. 42:326330.

15. Lingappa, Y., and Sussman, A. S. 1959. Changes in the heat-resistance of ascospores of Neurospora upon germination. Am. J. Bot. 46:671-678.

16. Mahroof, R., Subramanyamb, B., and Eustace, D. 2003. Temperature and relative humidity profiles during heat treatment of mills and its efficacy against Tribolium castaneum (Herbst) life stages. J. Stored Products Res. 39:555-569.

17. Moyano, C., and Melgarejo, P. 2002. Survival of Botrytis cinerea in soil in South-Eastern Spain. J. Phytopathol. 150:536-540.

18. Page, R. M., Sherf, A. F., and Morgan, T. L. 1947. The effect of temperature and relative humidity on the longevity of the conidia of Helminthosporium oryzae. Mycologia 39:158164.

19. Paul, G. C., Kent, C., and Thomas, C. R. 1992. Viability testing and characterization of germination of fungal spores by automatic image analysis. Biotechnol. Bioengineering 42:11-23.

20. Rotem, J. 1968. Thermoxerophytic properties of Alternaria porri f. sp. Solani. Phytopathology 58:1284-1287.

21. Sandhu, S. S., Rajak, R. C., and Agrawal, G. P. 1993. Studies on prolonged storage of Beauveria bassiana conidia: Effects of temperature and relative humidity on conidial viability and virulence against chickpea borer, Helicoverpa armigera. Biocontrol Sci. Technol. 3:47-53.

22. Schein, R. D., and Rotem, J. 1965. Temperature and humidity effects on uredospore viability. Mycologia 57:397-403.

23. Schirra, M., Mulas, M., Fadda, A., and Cauli, E. 2004. Cold quarantine responses of blood oranges to postharvest hot water and hot air treatments. Postharvest Biol. Technol. 31:191 200.

24. Shlevin, E., Mahrer, Y., and Katan, J. 2004. Effect of moisture on thermal inactivation of soilborne pathogens under structural solarization. Phytopathology 94:132-137.

25. Smilanick, J. L., Sorenson, D., Mansour, M. F., Aieyabei, J., and Plaza, P. 2003. Impact of a brief postharvest hot water drench treatment on decay, fruit appearance, and microbe populations of California lemons and oranges. HortTechnology 13:333-338.

26. Spotts, R. A. 1985. Environmental factors affecting conidial survival of five pear decay fungi. Plant Dis. 69:391-392.

27. Teitell, L. 1958. Effects of relative humidity on viability of conidia of Aspergilli. Am. J. Bot. 45:748-753.

28. Vázquez, D. E., Meier, G. E., and Ponte, M. 2005. Influence of postharvest curing on 'Marsh' grapefruit quality during long-term storage. Acta Hortic. 682:1257-1264.

29. Wardowski, W. L., Miller, W. M., and Grierson, W. 2006. Degreening. Pages 277-298 in Fresh Citrus Fruits. 2nd ed. W. F. Wardowski, W. M. Miller, D. J. Hall, and W. Grierson, eds. Florida Science Source, Inc., Longboat Key, FL. 